\title{
Expandindo 0 alcance, conquistando novas fronteiras
}

\author{
Expanding the scope, reaching new frontiers
}

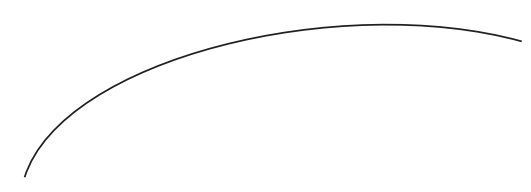

Mais um ano se inicia e, com ele, um novo número da Revista Brasileira de Geriatria e Gerontologia (RBGG).

Em 2014, comemoraremos nosso oitavo ano com a nova configuração. Os Textos sobre Envelhecimento, apesar de temporalmente mais distantes, serviram de base para o que somos hoje e fizeram emergir publicações numa área que era muito carente de bons trabalhos no Brasil, a Geriatria e Gerontologia.

A trajetória da RBGG tem sido marcada por grandes desafios e pautada na certeza de que, com a crescente produção científica na área, estaremos sempre abertos a publicar o que de melhor recebemos, tomando como base a grande quantidade de artigos recebidos e as dificuldades que são inerentes ao processo editorial.

A transitividade direta do verbo publicar nos remete ao fato de levarmos ao conhecimento do público algo, divulgar, propagar. E é essa nossa missão. Trazer ao conhecimento de pacientes, técnicos, pesquisadores e leitores de um modo geral o que é produzido na área da Geriatria e Gerontologia brasileira e internacional.

O Dicionário Online de Português apresenta uma citação do Marquês de Maricá, constante na definição do verbo publicar (http://www.dicio.com.br/publicar, acesso em 21 mar 2014) que diz: "Há verdades que é mais perigoso publicar do que foi difícil descobrir". No entanto, tais verdades precisam ser publicadas, a fim de que sejam produzidas as matérias-primas da Ciência, o que é passível de ser testado, confirmado ou refutado.

Este número da RBGG traz, como de costume, uma grande quantidade de temas afeitos à área da Geriatria e Gerontologia: cuidados paliativos, incontinência urinária, quedas, funcionalidade, aids, força muscular, autopercepção de idosos em relação à saúde e a sua inserção em grupos de convivência, dança e fisioterapia, medicamentos, qualidade de vida, depressão e cognição, redução de dor e doença de Parkinson compõem esse quadro. Trata-se, portanto, do espelho da produção científica brasileira que, a passos largos, vem crescendo em qualidade. Essa produção contempla neste número artigos do Sudeste brasileiro, toda a Região Sul, Nordeste e um artigo do estado de Rondônia, denotando claramente que a preocupação em estudar questões relacionadas ao envelhecimento humano, pouco a pouco, tem se tornado universal. 
Muito mais ainda temos que fazer. Consolidar as novas fronteiras conquistadas, ampliar o acesso a leitores estrangeiros, agilizar todo o processo editorial e nos tornarmos referência não só no território nacional, mas atravessarmos oceanos e implantarmos a bandeira do envelhecimento e da Geriatria e Gerontologia brasileira em terrenos que, certamente, na conjuntura atual, estão férteis ao nosso conhecimento.

Prof. Kenio Lima Editor Associado 